B , GELLA I

DETERMINATION OF MOLECULAR SYMMETRY COORDINATES USING CIRCULANT MATRICES

Hungarian Fcademy of Sciences

CENTRAL

RESEARCH

INSTITUTE FOR

PHYSICS

BUDAPEST 


\section{DETERMINATION OF MOLECULAR SYMMETRY \\ COORDINATES USING CIRCULANT MATRICES}

Barbara Gellai

Central Research Institute for Physics

H-1525 Budapest 114, P.O.B. 49, Hungary 


\section{ABSTRACT}

A special matrix theoretical method for obtaining molecular symmetry coordinates is described. The method is based on the diagonalization of the circulant blocks of $G$ kinetic and $F$ potential energy matrix representing the interaction of the sets of equivalent internal coordinates. The symmetry coefficients can be obtained by using a special polynomial relation between the circulant blocks and the basic circulant matrix. A general formula for the symmetry transformation matrix depending only on the order of the matrix is derived for matrices $G$ and $F$ being hypermatrices with circulant blocks and being circulant blockwise with circulant blocks. The application of the method has been demonstrated for the molecules $\mathrm{CH}_{3} \mathrm{X}, \mathrm{Y}\left(\mathrm{CH}_{3}\right)_{2}$ and $\mathrm{CH}_{2} \mathrm{Cl}_{2} \mathrm{and}$ the obtained symmetry coordinates are classified according to symmetry. An attempt was made to include into the method the removal of coordinate redundance.

\section{АННОТАЦИЯ}

Дается описание матричного способа вычисления координат симметрии молекул. Способ используется в случае, когда матрицы кинематических коэФфициентов G. и силовых постоянных F являются клеточными матрицами с циркулянтными блоками. КоэФФициенты симметрии можно вычислить из элементов собственных векторов, циркулянтно зависящих только от порядка блоков. Способ обобщается на случай, когда матрицы G и F являются клеточными циркулянтными с циркулянтными блоками Показано использование способа в случае молекул $\mathrm{CH}_{3} \mathrm{X}, \mathrm{Y}\left(\mathrm{CH}_{3}\right)_{2}$ и $\mathrm{CH}_{2} \mathrm{Cl}_{2} \cdot \mathrm{Kc}^{-}$ ключения зависимых координат было предусмотрено.

\section{KIVONAT}

Egy mátrixelméleti módszert ismertetünk molekulák szimmetriakoordinátáinak meghatározására. A módszer abban az esetben alkalmazható, ha a molekula G kinetikus és $\mathrm{F}$ potenciális energia mátrixa ciklikus blokkokból álló hipermátrix. A szimmetriakoordinátákban szereplő együtthatók a ciklikus blokkok sajátvektoraiból alkotott mátrixnak, a Fourier mátrixnak elemeibôl számithatók, amelyek csupán a mátrix rendjétól függenek. A módszer általánositható arra az esetre is, ha a G és F mátrix "többszintü" ciklikus hipermátrix, amelyben az egyes blokkok maguk is ciklikus blokkokból álló hipermátrixok. A módszer alkalmazását a $\mathrm{CH}_{3} \mathrm{X}, \mathrm{Y}\left(\mathrm{CH}_{3}\right)_{2}$ és a $\mathrm{CH}_{2} \mathrm{Cl}_{2}$ molekulák esetében mutatjuk be, s ez utóbbinál a redundáns koordináta kiküszöbölésére is példát adunk. 


\section{INTRODUCTION}

Symmetry coordinates that are appropriate linear combinations of the internal coordinates (i.e. changes of bond lengths and bond angles) are usually employed to factor the secular equation for the normal vibration of symmetrical molecules.

Besides the well known Wigner group theoretical methods $[1,2]$ several useful procedures for obtaining symmetry coordinates have previously been reported [3-13]. Most of these methods imply a knowledge of the transformation matrices under the symmetry operation of the point groups of the molecules.

In this paper a matrix theoretical method is described constructing symmetry coordinates of molecules whose Hamiltonian has a structure of a special circulant block. The method is related to those developed by Kilpatrick [3] and Morozov and Morozova as well [6] and is based on the diagonalization of the circulant matrices representing the interactions of the equivalent internal coordinates in the vibration space. The symmetry coefficients were derived using the spectral decomposition of the basic circulant. A general formula for the symmetry transformation matrix was constructed for cases when the matrices $\mathrm{G}$ and $\mathrm{F}$ have a circulant structure of higher level because of the molecular symmetry.

The method is applied to the molecules $\mathrm{CH}_{3} \mathrm{X}\left(\mathrm{C}_{3 \mathrm{v}}\right), \mathrm{Y}\left(\mathrm{CH}_{3}\right){ }_{2}(\mathrm{Y}=\mathrm{Zn}, \mathrm{Cd}, \mathrm{Hg})$ $\left(\mathrm{D}_{3 \mathrm{~d}}\right)$ for eclipsed rigid configuration and $\mathrm{CH}_{2} \mathrm{Cl}_{2}\left(\mathrm{C}_{2 \mathrm{v}}\right)$. In the case of the last molecule an attempt was made to include the removal of coordinate redundance into the method.

List of mathematical symbols

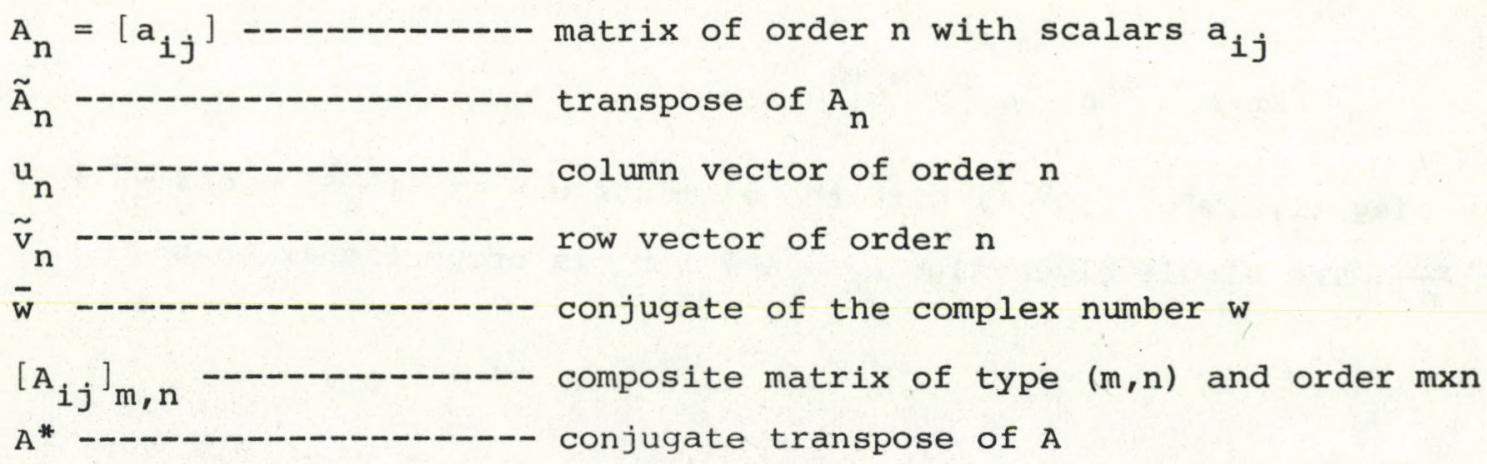


$\Sigma_{n}=\operatorname{diag}\left(\sigma_{1}, \ldots, \sigma_{n}\right) \ldots \ldots$ diagonal matrix with elements $\sigma_{i}$

$I_{n}$

$A \cdot x B=\left[a_{i j} B\right]-\ldots$ direct product of matrices $A$ and $B$

$\mathrm{A} \oplus \mathrm{B}=\operatorname{diag}(\mathrm{A}, \mathrm{B})=$

= ( $\left.\begin{array}{c|c}\mathrm{A} & \mathrm{O} \\ \hline \text { O/B }\end{array}\right)$

$\tilde{u} \cdot x \tilde{v}=\left[u v_{1}, u v_{2}, \ldots, u v_{n}\right]=\left[u_{1} v_{1}, u_{2} v_{1}, \ldots, u_{n} v_{1}\right]$

$\left.u_{1} v_{2}, u_{2} v_{2}, \ldots, u_{n} v_{2}: \ldots, u_{1} v_{n}, u_{2} v_{n}, \ldots, u_{n} v_{n}\right] \ldots$ direct product of

$\mathrm{A} \in \mathrm{B}_{\mathrm{m}, \mathrm{n}}$

\section{I. THE METHOD}

If the internal coordinates of a molecule can be divided into sets of equivalent coordinates that are transformed among themselves under the symmetry operations of the molecule then the reduction to irreducible representations of the matrix GF of the vibration operator is equivalent to diagonalization of its submatrices representing the interactions of the equivalent coordinates of a different kind. Because of the molecular symmetry these submatrices (for three equivalent coordinates) have the circulant form

$$
\operatorname{circ}(a, b, b)=\left(\begin{array}{lll}
a & b & b \\
b & a & b \\
b & b & a
\end{array}\right) .
$$

Matrices of this type are characterized by the first row; their spectral decomposition (proved in the Appendix) can be written for odd order $\mathrm{n}=2 \mathrm{~m}+1$ as:

$$
\begin{aligned}
A_{2 m+1} & =\operatorname{circ}\left(a, b_{1}, b_{2}, \ldots, b_{m}, b_{m}, \ldots, b_{1}\right)= \\
& =\widetilde{f}_{2 m+1}^{\Lambda_{2 m+1}} \widetilde{f}_{2 m+1}
\end{aligned}
$$

where

$$
\Lambda_{2 m+1}=a I_{n}+\sum_{v=1}^{m} b_{v}\left(\Omega_{n}^{\nu}+\Omega_{n}^{-v}\right)
$$

and $\Omega_{\mathrm{n}}=\operatorname{diag}\left(1, \mathrm{w}, \mathrm{w}^{2}, \ldots, \mathrm{w}^{\mathrm{n}-1}\right)$ with the $\underset{\mathrm{m}}{\operatorname{elements} \mathrm{w}}=\exp \left(\frac{2 \pi i}{\mathrm{n}}\right)=\cos \frac{2 \pi}{\mathrm{n}}+$ $+i \cdot \sin \frac{2 \pi}{n}$. The single eigenvalue $\lambda_{0}=a+2 \sum_{\nu=1}^{m} b_{\nu}$ is proportional to the 
frequency of the symmetrical vibration; the multiple eigenvalues $\lambda_{k}=a+2 \sum_{v=1}^{m} b_{v} \cos \frac{2 \pi \nu k}{2 m+1}(k=1,2, \ldots, m)$ give the frequencies of double degenerate vibrations.

For even order $\mathrm{n}=2 \mathrm{~m}$

$$
A_{2 m}=\operatorname{circ}\left(a, b_{1}, b_{2}, \ldots, b_{m}, \ldots, b_{2}, b_{1}\right)=\widetilde{f}_{2 m} \Lambda_{2 m} \widetilde{f}_{2 m}
$$

where

$$
\Lambda_{2 m}=a I_{n}+\sum_{\nu=1}^{m-1} b_{\nu}\left(\Omega_{n}^{\nu}+\Omega_{n}^{-\nu}\right)+b_{m} \Omega_{n}^{m}
$$

The single eigenvalues $\lambda_{0}=a+2 \sum_{v=1}^{m-1} b_{v}+b_{m}$ and $\lambda_{n}=a+2 \sum_{v=1}^{m-1}(-1) v_{v}+(-1) b_{m}$ are proportional to the symmetrical and antisymmetrical vibrational frequencies respectively; the double degenerate vibrational frequencies can be obtained from the eigenvalues $\lambda_{k}=a+2 \sum_{v=1} b_{v} \cos \frac{k \pi v}{m}+(-1)^{k_{b}}(k=1,2, \ldots, m-1)$. The eigenvector matrix (for proof, see Appendix) is:

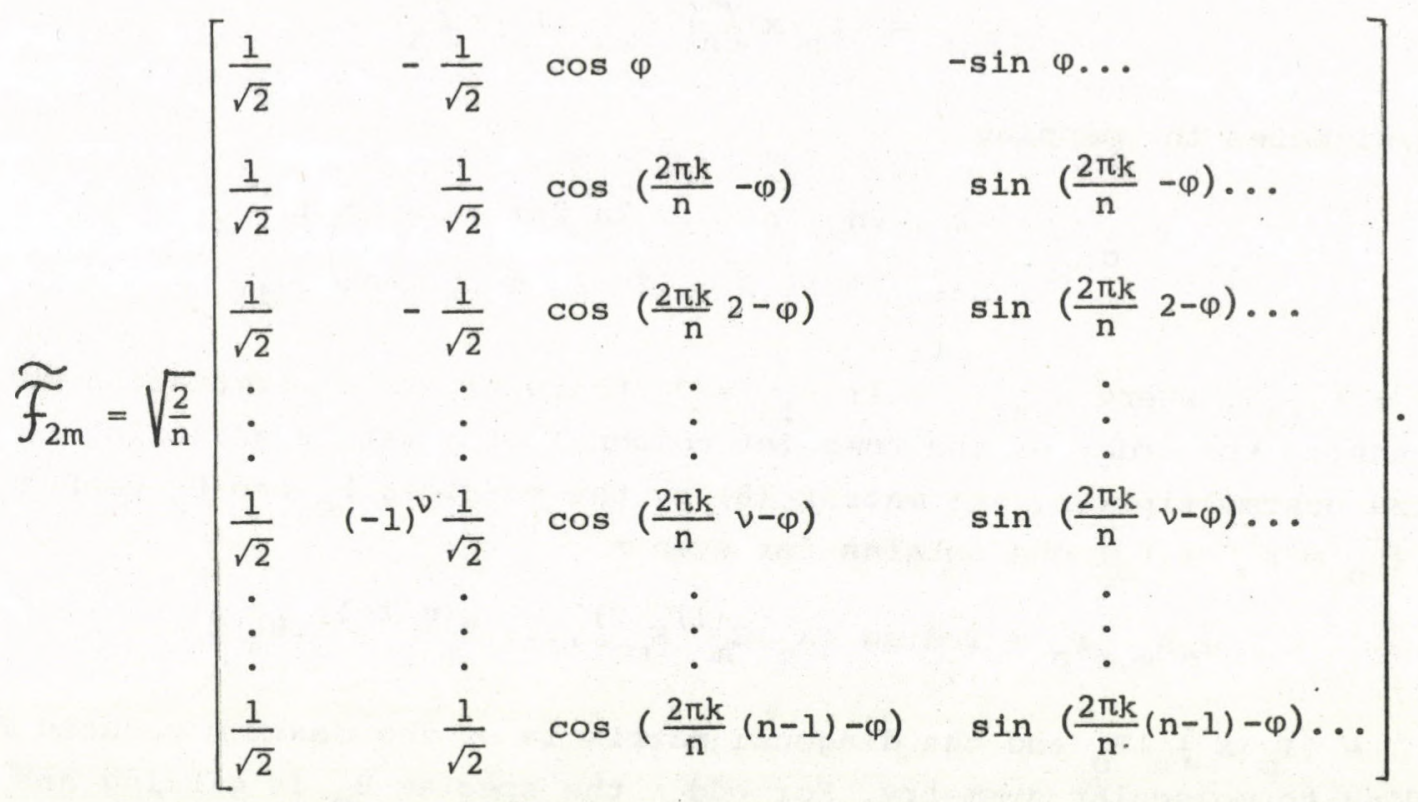

The first column belongs to the symmetric the second to the antisymmetric species; the cosine and sine column pairs correspond to the double degenerate species $E_{i}(i=1,2, \ldots,(n-1))$ (the second column for odd order is missing). By changing the value of parameter $\varphi$ we can achieve the simultaneous transformation of the degenerate coordinates ([14], p.287). For odd $n$ ( $n$ is the order of the rotation axis) $\varphi=0$ and for even $n, \varphi=\pi / n$. However the numbering of the internal coordinates should follow the rule: e.g. for odd order molecules $\mathrm{CH}_{3} \mathrm{X}(\mathrm{n}=3), \alpha_{1}=r_{1}{ }^{\not r_{3}}, \alpha_{2}=r_{1}{ }^{x r_{3}}, \alpha_{3}=r_{1} \not r_{2} ; \beta_{i}=r_{i} \not C-x$ $(i=1,2,3)$; for even order, e.g. the molecule XY $4(n=4), a_{i}=r_{i} \times r_{i+1}$ $(i=1,2,3,4)$. 
According to the number and type of the symmetry elements the matrices $\mathrm{G}$ and $\mathrm{F}$ can be:

(a) Symmetrical hypermatrix with circulant blocks

Designation of the class of these matrices: $\zeta_{0} B_{m, n}$

An $n$-fold rotation axis and $m$ vertical planes $\left(C_{n v}\right)$ cause matrices $G$ and $F$ to be $A_{m, n}=\left[A_{i j}\right]_{m, n}$ which consists of $m$ blocks each being a circulant matrix of order $n$. Thus $A_{m, n} \in \mathcal{S}_{m, n}$.

The spectral decomposition of the blocks $A_{i j}(i, j=1,2, \ldots, m)$ is of the form

$$
A_{i j}=\widetilde{f}_{n} \Lambda_{i j} \tau_{n}
$$

where, if the order of the block is odd, $\Lambda_{i j}(i, j=1,2, \ldots, m)$ are diagonal matrices of type (3) and, if $\mathrm{n}$ is even of type (5) respectively with the appropriate coefficients, $a_{i j}, b_{i j}(i, j=1,2, \ldots, m)$.

The decomposition of matrix $A_{m, n}=\left[A_{i j}\right]_{m, n} \in \zeta \beta_{m, n}$ is as follows:

$$
A_{m, n}=\left(I_{m} \cdot x \widetilde{F}_{n}\right)\left[\Lambda_{i j}\right]\left(I_{m} \cdot x \widetilde{F}_{n}\right)
$$

If $\sigma$ designates the mapping



then $P=\left[a_{i j}\right]$, where $a_{i \sigma(i)}=1 ; a_{i j}=0$ otherwise, is a permutation matrix that changes the order of the rows (or columns) of a matrix according to $\sigma$. Pre- and postmultiplying the matrix (8) by the matrices $\tilde{\mathrm{P}}_{\sigma}$ and $\mathrm{P}_{\sigma}$ respectively $\left(\tilde{P}_{\sigma}=P_{\sigma}^{-1}=P_{\sigma}\right)$ one obtains for even $n$

$$
\tilde{\mathrm{P}}_{\sigma} \mathrm{A}_{\mathrm{m}, \mathrm{n}^{\mathrm{P}} \sigma}=\tilde{\mathrm{T}} \operatorname{diag}\left(\mathrm{A}_{\mathrm{m}}, \mathrm{E}_{\mathrm{m}}^{(1)} \mathrm{E}_{\mathrm{m}}^{(2)}, \ldots, \mathrm{E}_{\mathrm{m}}^{(\mathrm{n} / 2-1)}, \mathrm{B}_{\mathrm{m}}\right) \mathrm{T}
$$

where $T=\left(I_{m} \cdot x \mathcal{F}_{n}\right) P_{\sigma}$ and the diagonal matrix is of the maximum reduced form according to molecular symmetry. For odd $\mathrm{n}$ the species $\mathrm{B}_{\mathrm{m}}$ is $\mathrm{missing}$ and the superscript of the species $E$ runs instead of $n / 2-1$ up to $(n-1) / 2$.

(b) Symmetrical hypermatrix which are block circulant with circulant blocks

\section{Designation of the class of these matrices: 3$\}\}_{3 m, n}$}

The presence of $a C_{n}$ rotation axis and symmetry planes perpendicular to it (for example $D_{n d}$ ) cause matrices $G$ and $F$ to be $A_{m, n}=\operatorname{circ}\left(A_{1} A_{2} \ldots A_{m}\right.$ ) where each block is a circulant of order $n$. Matrices of this kind are block circulant with circulant blocks.

It can easily be seen by using the appropriate power of the basic circulant $c_{m}=\operatorname{circ}(0,1, \ldots, 0)$ (see Appendix) that 


$$
A_{m, n}=\operatorname{circ}\left(A_{0} A_{1} \cdots A_{m-1}\right)=\sum_{k=0}^{m-1} C_{m}^{k} \cdot x A_{k} \cdot
$$

Substituting the decomposition $c_{m}=\widetilde{F}_{m}^{8} \widetilde{F}_{m}$ (for proof see Appendix) and the decomposition of type (7) into equn. (11) we obtain the spectral decomposition of a block circulant with circulant blocks as

$$
A_{m, n}=\operatorname{circ}\left(A_{0} A_{1} \ldots A_{m}\right)=\left(\widetilde{F}_{m} \cdot x \widetilde{F}_{n}\right)\left(\sum_{k=0}^{m-1} s_{m}^{k} \cdot x \Lambda_{k}\right)\left(\mathcal{F}_{m} \cdot x \mathcal{F}_{n}\right)
$$

where $\Lambda_{k}$ is a diagonal matrix of type (3) if $n$ is odd and of type (5) if $n$ is even. It is convenient to determine the symmetry type of each individual row of the matrix $T=\left(\mathcal{F}_{\mathrm{m}} \cdot \mathrm{x} \mathcal{F}_{\mathrm{n}}\right)$ at the application of the method for a given molecule.

\section{I. APPLICATION}

The potential energy matrix of the methyl halides $\mathrm{CH}_{3} \mathrm{X}\left(\mathrm{C}_{3 \mathrm{v}}\right)$ written in the internal valence coordinates $\Delta R_{,} \Delta r_{i}, \Delta \alpha_{i}, \Delta \beta_{i}(i=1,2,3)$ is

$$
F=\left[\begin{array}{c:c}
f_{11} & \tilde{f}_{1} \cdot x \tilde{u} \\
\hdashline f_{1} \cdot x u & {\left[F_{i j}\right]}
\end{array}\right],
$$

where the blocks $F_{i j}(i, j=1,2,3)$ are symmetric circulant matrices of order $3, f_{1}$ is the first eigenvector of the blocks $F_{i j}$ while the vector $\tilde{\mathrm{u}}=(\sqrt{3} \mathrm{~b}, \sqrt{3} \mathrm{c}, \sqrt{3} \mathrm{~d})$. The matrix $\left[\mathrm{F}_{i j}\right]_{3,3}$ is a composite symmetric matrix of type $(3,3)$ so $\left[F_{i j}\right]_{3,3} \in \mathcal{G}_{\circ} B_{3,3}$. Therefore by using the transformation matrix $T=\operatorname{diag}\left(1,\left(I_{3} \cdot \times F_{3}\right) P_{\sigma}\right)$ where

$$
f_{3}=\left[\begin{array}{ccc}
\frac{1}{\sqrt{3}} & \frac{1}{\sqrt{3}} & \frac{1}{\sqrt{3}} \\
\frac{-1}{\sqrt{6}} & \frac{-1}{\sqrt{6}} & \frac{2}{\sqrt{6}} \\
\frac{-1}{\sqrt{2}} & \frac{1}{\sqrt{2}} & 0
\end{array}\right]
$$

and $P_{\sigma}$ is the permutation mațrix corresponding to the following mapping

$$
\sigma:\left[\begin{array}{lllllllll}
1 & 2 & 3 & 4 & 5 & 6 & 7 & 8 & 9 \\
1 & 4 & 7 & 2 & 5 & 8 & 3 & 6 & 9
\end{array}\right]
$$

we obtain the reduced form of matrix $F$ as 


$$
\tilde{\mathrm{TFT}}=\operatorname{diag}\left(\mathrm{F}_{4}^{(\mathrm{a})}, \mathrm{F}_{3}^{(\mathrm{e})}, \mathrm{F}_{3}^{(\mathrm{e})}\right)
$$

where

$$
F_{4}^{(a)}=\left[\begin{array}{c:c}
f_{11} & \tilde{u} \\
\hdashline u & F_{3}^{(a)}
\end{array}\right]
$$

and $F_{3}^{(a)}$ is a $3 \times 3$ block with the elements $f_{i j}^{(a)}=a_{i j}+2 b_{i j}(i, j=1,2,3)$ while the two identical blocks $\mathrm{F}^{(e)}$ of order three are the double degenerate representations with the elements $F_{i j}^{(e)}=a_{i j}-b_{i j}$.

Since the order of the rotation axis or what is the same the order of matrix (14) $\mathrm{n}=3$ is odd we know in advance that there is not an antisymmetric species but there is $(n-1) / 2=1$ a double degenerate species. So it is easy to establish that the first row of matrix (14) belongs to the symmetric, the second and third rows to the double degenerate species. The multiplication of matrix (14) and the valence bond length vector $\Delta r=\left(\Delta r_{1}, \Delta r_{2}, \Delta r_{3}\right)$ together with $\Delta R$ give the symmetry valence bond stretching coordinates (Table I).

\section{Table I}

Set of symmetry bond stretching coordinates for $\mathrm{CH}_{3} \mathrm{X}\left(\mathrm{C}_{3 \mathrm{v}}\right)$

$$
\begin{aligned}
& S(a)=(1 / \sqrt{3})\left(\Delta r_{1}+\Delta r_{2}+\Delta r_{3}\right) \\
& S_{1}(e)=(1 / \sqrt{6})\left(2 \Delta r_{1}-\Delta r_{2}-\Delta r_{3}\right) \\
& S_{2}(e)=(1 / \sqrt{6})\left(\Delta r_{2}-\Delta r_{3}\right) \\
& S(a)=\Delta R
\end{aligned}
$$

We can get similar expressions for the valence angle bending $\Delta \alpha_{i}, \Delta \beta_{i}(i=1,2,3)$. So the reduced form (16) is the maximum one according to the molecular symmetry.

- In the case of the molecules for eclipsed rigid configuration $\mathrm{Y}\left(\mathrm{CH}_{3}\right)_{2}\left(\mathrm{D}_{3 \mathrm{~d}}\right) \quad(\mathrm{Y}=\mathrm{Zn}, \mathrm{Cd}, \mathrm{Hg})$ (Fig. 1) the sets of the equivalent internal

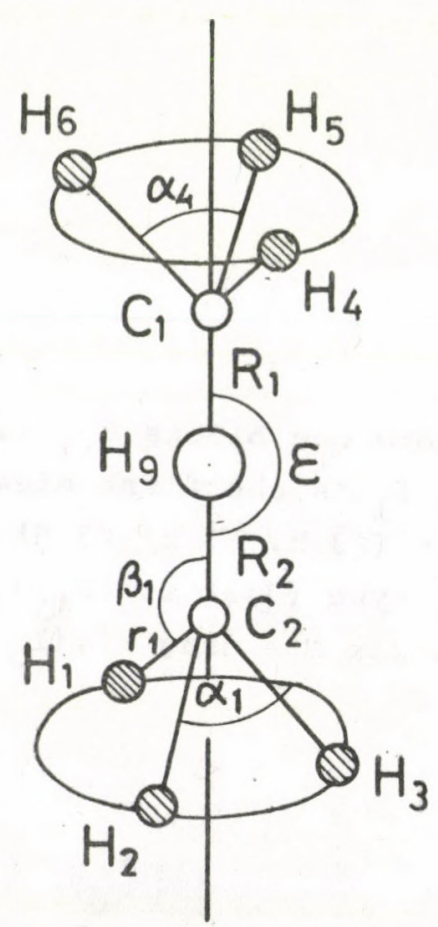

Fig. 1. Symmetry of the molecule $\mathrm{Y}\left(\mathrm{CH}_{3}\right)_{2}$ and its internat coordinates coordinates are a consequence of a threefold rotation axis $C_{3}$ and a plane $\sigma_{n}$ perpendicular to it. The potential energy matrix in terms of the internal coordinates $\Delta R_{1}, \Delta R_{2}, \Delta r_{i}, \Delta \alpha_{i}, \Delta \beta_{i}$ $(i=1,2, \ldots, 6), \Delta \varepsilon, \Delta \varepsilon^{\prime}$ is: 


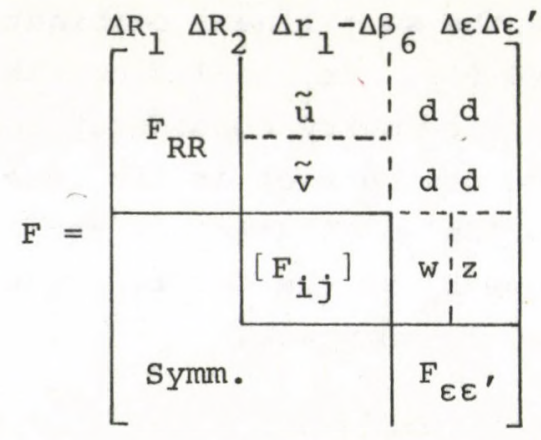

where the blocks $F_{R R}=\operatorname{circ}(a, b),\left[F_{1 j}\right]_{3,6}$ and $F_{\varepsilon \varepsilon^{\prime}}=\operatorname{diag}(c, c)$ belong to the interactions of the equivalent internal coordinate groups $\left(\Delta \mathrm{R}_{1}, \Delta \mathrm{R}_{2}\right)$, $\left(\Delta \mathrm{r}_{1}, \ldots, \Delta \beta_{6}\right)$ and $\left(\Delta \varepsilon, \Delta \varepsilon^{\prime}\right)$ respectively. The block $\left[F_{i j}\right]_{3,6} \in \zeta_{B} \mathbb{B}_{3,6}$ while each $F_{i j} \in B \zeta \zeta_{0} B_{2,3}$.

Therefore by applying a combination of the decomposition formulae

and (8) we obtain the symmetry transformation matrix

$$
T=\operatorname{diag}\left(\mathcal{F}_{2}, I_{3} \cdot x\left(\mathcal{F}_{2} \cdot x \mathcal{F}_{3}\right), I_{2}\right)
$$

which diagonalizes the blocks belonging to the interactions of the equivalent coordinate groups. In equn. (19)

$$
\mathcal{F}_{2}=\frac{1}{\sqrt{2}}\left[\begin{array}{rr}
1 & 1 \\
1 & -1
\end{array}\right]
$$

and $F_{3}$ is matrix (14). On the basis of the symmetry point group of the molecule, matrix $\mathcal{F}_{2}$ belongs to the symmetry operation $i$ so its rows are of type $A_{g}$ and $A_{u}$. Thus, by using the symmetry type of the rows of $\mathcal{F}_{3}$ established in the previous molecule and the rule of multiplication properties of direct products of irreducible representations ([1], p.331) one obtains

$$
\mathcal{F}_{2} \times \mathcal{F}_{3}=\left[\begin{array}{ccc:ccc}
\frac{1}{\sqrt{6}} & \frac{1}{\sqrt{6}} & \frac{1}{\sqrt{6}} & \frac{1}{\sqrt{6}} & \frac{1}{\sqrt{6}} & \frac{1}{\sqrt{6}} \\
\frac{2}{\sqrt{12}} & \frac{-1}{\sqrt{12}} & \frac{-1}{\sqrt{12}} & \frac{2}{\sqrt{12}} & \frac{-1}{\sqrt{12}} & \frac{-1}{\sqrt{12}} \\
0 & \frac{1}{2} & -\frac{1}{2} & 0 & \frac{1}{2} & \frac{-1}{2} \\
\hdashline \frac{1}{\sqrt{6}} & \frac{1}{\sqrt{6}} & \frac{1}{\sqrt{6}} & \frac{-1}{\sqrt{6}} & \frac{-1}{\sqrt{6}} & \frac{-1}{\sqrt{6}} \\
\frac{2}{\sqrt{12}} & \frac{-1}{\sqrt{12}} & \frac{-1}{\sqrt{12}} & \frac{-2}{\sqrt{12}} & \frac{1}{\sqrt{12}} & \frac{1}{\sqrt{12}} \\
0 & \frac{1}{2} & \frac{-1}{2} & 0 & \frac{-1}{2} & \frac{1}{2}
\end{array}\right\} \mathrm{A}_{\mathrm{g}}
$$

Multiplication of matrix (2l) with the vector $\Delta \mathrm{r}=\left(\Delta \mathrm{r}_{1}, \ldots, \Delta \mathrm{r}_{6}\right)$ and matrix $\mathcal{F}_{2}$ with the vector $\left(\Delta \mathrm{R}_{1}, \Delta \mathrm{R}_{2}\right)$ gives the symmetry stretching coordinates to 
be seen in Table II. We obtain the same linear combinations for $\Delta \alpha_{i}, \Delta \beta_{i}$ $(i=1,2, \ldots, 6)$ as was obtained for $\Delta r_{i}$ including the redundance whose presence is necessary because of symmetry considerations. An attempt to include the removal of redundance can be seen in the case of the following molecule. The internal deformation coordinates $\Delta \varepsilon$ and $\Delta \varepsilon$ ' are themselves symmetry coordinates of the type $\mathrm{E}_{\mathrm{u}}$ so the determination of the symmetry type of the rows of matrix (19) is complete.

\section{Table II}

Symmetry stretching coordinates for the molecules $\mathrm{Y}\left(\mathrm{CH}_{3}\right)_{2}\left(\mathrm{D}_{3 \mathrm{~d}}\right)$

$$
\begin{aligned}
& S\left(a_{l g}\right)=\frac{1}{\sqrt{6}}\left(\sum_{i=1}^{3} \Delta r_{i}+\sum_{j=4}^{6} \Delta r_{i}\right) \\
& \mathrm{s}\left(\mathrm{a}_{1 \mathrm{~g}}\right)=\frac{1}{\sqrt{2}} \quad\left(\Delta \mathrm{R}_{1}+\Delta \mathrm{R}_{2}\right) \\
& \left\{\begin{array}{l}
S^{(a)}\left(e_{g}\right)=\frac{1}{\sqrt{12}}\left(2 \Delta r_{1}-\Delta r_{2}-\Delta r_{3}+2 \Delta r_{4}-\Delta r_{5}-\Delta r_{6}\right) \\
S^{(b)}\left(e_{g}\right)=\frac{1}{2}\left(\Delta r_{2}-\Delta r_{3}+\Delta r_{5}-\Delta r_{6}\right)
\end{array}\right. \\
& \dot{S}\left(a_{2 u}\right)=\frac{1}{\sqrt{6}}\left(\sum_{i=1}^{3} \Delta r_{i}-\sum_{j=4}^{6} \Delta r_{i}\right)^{\prime} \\
& S\left(a_{2 u}\right)=\frac{1}{\sqrt{2}} \cdot\left(\Delta R_{1}-\Delta R_{2}\right) \\
& \left\{\begin{array}{l}
S^{(a)}\left(e_{u}\right)=\frac{1}{\sqrt{12}}\left(2 \Delta r_{1}-\Delta r_{2}-\Delta r_{3}-2 \Delta r_{4}+\Delta r_{5}+\Delta r_{6}\right) \\
S^{(b)}\left(e_{u}\right)=\frac{1}{2}\left(\Delta r_{2}-\Delta r_{3}-\Delta r_{4}+\Delta r_{6}\right)
\end{array}\right.
\end{aligned}
$$

The $\mathrm{CH}_{2} \mathrm{Cl}_{2}$ molecule (Fig. 2) is of lower symmetry than the previous two, however, the method works well in this case too. Matrix F, in terms of internal coordinates, is

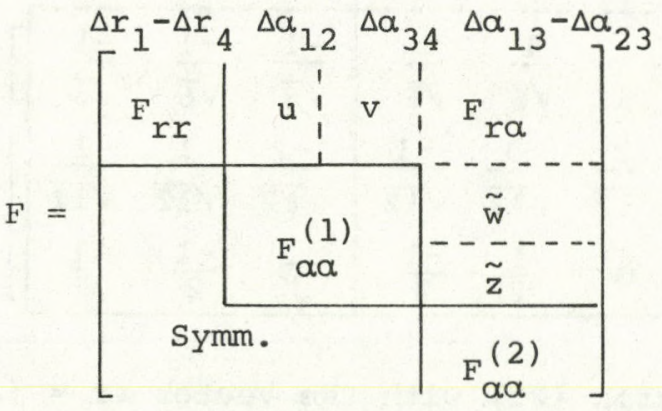




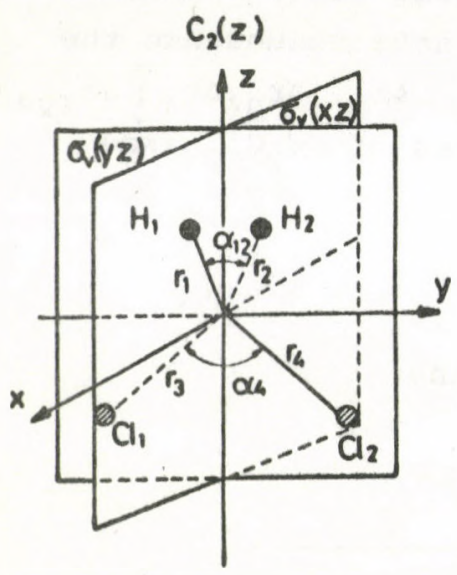

Fig. 2. Symmetry of the $\mathrm{CH}_{2} \mathrm{Cl} \mathrm{l}_{2}$ molecule and its internal coordinates where the blocks presenting the interaction of the equivalent coordinates are $\mathrm{F}_{\mathrm{rr}} \mathrm{F}_{\mathrm{a \alpha}}^{(1)}$ and $\mathrm{F}_{\alpha \alpha}^{(2)}$. According to their structures $F_{r r} \in \zeta B_{2,2} F_{\alpha \alpha}^{(1)}=\operatorname{circ}$ $(a, b)$ and $\left.F_{\alpha \alpha}^{(2)} \in \mathbb{B} \rho\right\} B_{2,2}$. Therefore the matrix which diagonalizes these blocks is

$$
T=\left(I_{3} \cdot \times F_{3}\right) \oplus\left(\mathcal{F}_{2} \cdot \times F_{2}\right)
$$

where $\mathcal{F}_{2}$ is matrix $(20)$, i.e. the same matrix belongs to each pair of internal coordinates $\left(\Delta \mathrm{r}_{1}, \Delta \mathrm{r}_{2}\right),\left(\Delta \mathrm{r}_{3}, \Delta \mathrm{r}_{4}\right)$ and $\left(\Delta \alpha_{12}, \Delta \alpha_{34}\right)$. However the symmetry type of the rows of the blocks is different. Because the order of the rotation axis $\mathrm{n}=2$ is less than three there are only symmetric and antisymmetric species. On the basis of the molecular symmetry the species of the rows of the block in order are $\left(a_{1}, b_{1}\right),\left(a_{1}, b_{2}\right)$ and $\left(a_{1}, a_{1}\right)$. By applying the multiplication rule of the species of the first two blocks one obtains

$$
\left.\mathcal{F}_{2} \cdot \times \mathcal{F}_{2}=\left[\begin{array}{rr:rr}
\frac{1}{2} & \frac{1}{2} & \frac{1}{2} & \frac{1}{2} \\
\frac{1}{2} & -\frac{1}{2} & \frac{1}{2} & -\frac{1}{2} \\
\hdashline \frac{1}{2} & \frac{1}{2} & -\frac{1}{2} & -\frac{1}{2} \\
\frac{1}{2} & -\frac{1}{2} & -\frac{1}{2} & \frac{1}{2}
\end{array}\right]\right\} \begin{array}{ll}
a_{1} \\
\} & b_{2} \\
a_{2}
\end{array}
$$

Choosing the permutation matrix $\mathrm{P}_{\sigma}$ as

$$
\mathrm{P}_{\sigma}=\left[\begin{array}{c}
\mathrm{P} \mathrm{a}_{1} \\
\mathrm{P}_{\mathrm{b}_{1}} \\
\mathrm{P}_{\mathrm{b}_{2}} \\
\mathrm{P} \mathrm{a}_{2}
\end{array}\right]
$$

with the blocks

$$
\mathrm{P}_{\mathrm{a}_{1}}=\left[\begin{array}{l}
\tilde{\mathrm{e}}_{1} \\
\tilde{\mathrm{e}}_{3} \\
\frac{-2}{\sqrt{6}} \tilde{\mathrm{e}}_{5}+\frac{1}{\sqrt{3}} \tilde{\mathrm{e}}_{7} \\
\tilde{\mathrm{e}}_{6}
\end{array}\right], \mathrm{P}_{\mathrm{b}_{1}}=\left[\begin{array}{l}
\tilde{\mathrm{e}}_{2} \\
\tilde{\mathrm{e}}_{8}
\end{array}\right], \mathrm{P}_{\mathrm{b}_{2}}=\left[\begin{array}{l}
\tilde{\mathrm{e}}_{4} \\
\tilde{\mathrm{e}}_{10}
\end{array}\right], \mathrm{P}_{\mathrm{a}_{2}}=\tilde{\mathrm{e}}_{9}
$$


where the $e_{i}^{\prime s}$ are unit vectors of order 10 and the special linear combination of the vectors $\tilde{e}_{5}$ and $\tilde{e}_{7}$ is used to remove coordinate redundance the result of the matrix-vector product $\mathrm{P}_{\sigma} \mathrm{Ts}$ where $\tilde{\mathrm{s}}=\left(\Delta \mathrm{r}_{1}, \Delta \mathrm{r}_{2}, \Delta \mathrm{r}_{3}, \Delta \mathrm{r}_{4}, \Delta \alpha_{12}\right.$, $\left.\Delta \alpha_{34}: \Delta \alpha_{13}, \Delta \alpha_{23}, \Delta \alpha_{14}, \Delta \alpha_{24}\right)$ gives the symmetry coordinates of $\mathrm{CH}_{2} \mathrm{Cl}_{2}$ (see Table' III).

\section{$\underline{\text { Table III }}$}

Normalized symmetry coordinates for the $\mathrm{CH}_{2} \mathrm{Cl}_{2}$ molecule



It should be noted that the method in its present form is suitable for determining molecular symmetry coordinates only when the reduced form of the representation of the molecule's point group does not contain triple degenerate representations. This means that for triple degenerate species, matrix (6) should contain three angle parameters instead of one $(\varphi)$ in order to ensure the simultaneous transformation of the triple degenerate species.

\section{ACKNOWLEDGEMENT}

I am indebted to Professor J. Mink for his criticism of the paper. 


\section{APPENDIX}

The definition of the basic circulant of order $\mathrm{n}$ is

$$
c_{n}=\operatorname{circ}(0,1, \ldots, 0)
$$

the elements of which are defined as

$$
C_{j k}=\left\{\begin{array}{ll}
1 & \text { if } j=k-1 \\
0 & \text { if } j \neq k-1
\end{array} \text { mod } n\right. \text {. }
$$

Its spectral decomposition is

$$
c_{n}=\mathcal{F}_{n}^{*} \& \mathcal{F}_{n}
$$

where

$$
\Omega=\operatorname{diag}\left(1, w, w^{2}, \ldots, w^{(n-1)}\right)
$$

and $\mathcal{F}_{\mathrm{n}}$ is the so-called Fourier matrix of order $n$

$$
\mathcal{F}_{n}^{*}=\frac{1}{\sqrt{n}}\left[w^{(i-1)(j-1)}\right] \quad 1, j=1,2, \ldots,(n-1)
$$

with the elements $w=\exp \left(\frac{2 \pi i}{n}\right)=\cos \frac{2 \pi}{n}+i \sin \frac{2 \pi}{n} \quad i=\sqrt{-1}$.

By multiplying matrix (31) by matrix (30) the $j$-th row of the matrix product

$$
\frac{1}{\sqrt{n}}\left(w^{(j-1) \ell} w^{\ell}\right)=\frac{1}{\sqrt{n}} w^{j \ell} \quad l=0,1, \ldots,(n-1)
$$

then multiplying equn. (32) with the $k$-th column $(1 / \sqrt{n})\left(\bar{w}^{(k-1) r}\right)$ $(r=0,1, \ldots,(n-1))$ of matrix (31) and taking into account the relation $\mathrm{w}^{-\mathrm{k}}=\mathrm{w}^{-\mathrm{k}}=\mathrm{w}^{\mathrm{n}-\mathrm{k}}$ we obtain the $(j, k)-$ th element of matrix (29) to be .

$$
\frac{1}{n} \underset{r=0}{n-1} w^{j r_{w}}(k-1) r=\frac{1}{n} \underset{r=0}{n-1} w^{r(j-k+1)}=\left\{\begin{array}{ll}
1 & \text { if } j=k-1 \\
0 & \text { if } j \neq k-1
\end{array} \bmod n .\right.
$$

this is equivalent to definition (28) ([15] p.72).

By using the relation $c_{n}^{-k}=c_{n}{ }^{n-k}$ we can easily see that any circulant matrix of order $n$ can be written as a maximum $(n-1)$-th order polynomial of the basic circulant matrix of order $n$. That is, for odd $n=2 m+1$

$$
\begin{aligned}
A_{2 m+1} & =\operatorname{circ}\left(a, b_{1}, b_{2}, \ldots, b_{m}, b_{m}, \ldots, b_{1}\right)= \\
& =a I_{n}+\sum_{\nu=1}^{m} b_{v}\left(c_{n}^{\nu}+c_{n}^{-\nu}\right)
\end{aligned}
$$


and for even order $n=2 m$

$$
\begin{aligned}
A_{2 m} & =\operatorname{circ}\left(a_{1}, b_{1}, b_{2}, \ldots, b_{m}, \ldots, b_{2}, b_{1}\right)= \\
& =a I_{n}+\sum_{v=1}^{m-1} b_{v}\left(c_{n}^{\nu}+C_{n}^{-v}\right)+b_{m} c_{n}^{m} .
\end{aligned}
$$

Substituting equn. (29) into equns. (34) and (35) one obtains

$$
A_{2 m+1}=\tilde{f}_{2 m+1}^{*}\left\{a I_{n}+\sum_{v=1}^{m} b_{v}\left(\Omega_{n}^{\nu}+\Omega_{n}^{-\nu}\right)\right\} F_{2 m+1}
$$

and

$$
A_{2 m}=\mathcal{F}_{2 m}^{*}\left\{a I_{n}+\sum_{\nu=1}^{m-1} b_{v}\left(\Omega_{n}^{\nu}+\Omega_{n}^{-\nu}\right)+b_{m} \Omega_{n}^{m}\right\} \mathcal{F}_{2 m} .
$$

By substituting equn. (30) into equns. (35) and (36) we obtain for the eigenvalues of $\mathrm{A}_{2 \mathrm{~m}+1}$ [16]

$$
\lambda_{0}=a+2 \sum_{v=1}^{m} b_{v}
$$

and

$$
\lambda_{k}=a+2 \sum_{\nu=1}^{m} b_{v} \cos \frac{2 \pi \nu k}{2 m+1} \quad k=1,2, \ldots, m
$$

while for the eigenvalues of $A_{2 m}$

$$
\begin{aligned}
& \lambda_{0}=a+2 \sum_{v=1}^{m-1} b_{v}+b_{m} \\
& \lambda_{n}=a+2 \sum_{v=1}^{m-1}(-1){ }^{\nu} b_{v}+(-1) m_{m}
\end{aligned}
$$

and

$$
\lambda_{k}=a+2 \sum_{v=1}^{m-1} b_{v} \cos \frac{k \pi v}{m}+(-1) k_{m}
$$

Equations (38)-(42) show that any symmetric circulant matrix of odd order $(n=2 m+1)$ has one single and $m$ double eigenvalues whereas any symmetric circulant matrix of even order $(n=2 m)$ has two single and (m-1) double eigenvalues.

By using the following linear combinations of the column vectors of matrix (31) [16]

$$
\frac{1}{\sqrt{2}}\left(f_{k}+f_{2 m+1-k}\right) \quad \text { and } \frac{1}{i \sqrt{2}}\left(f_{k}-f_{2 m+1-k}\right) \quad k=1,2, \ldots, m
$$

the imaginary parts of the eigenvectors can be elimated and we obtain matrix (6) for even order. For odd order the second column is missing. 


\section{REFERENCES}

[1] E.B. Wilson, J. Decius and P. Cross, Molecular Vibrations, McGraw-Hill, New York, 1955.

[2] E.P. Wigner, Group Theory, Academic Press, New York, 1959.

[3] J.E. Kilpatrick, J.Chem. Phys. 16, 749 (1948).

[4] J.R. Nielsen and L.H. Berryman, J. Chem. Phys. 17, 659 (1949)

[5] B. Crawford, J. Chem. Phys. 21, 1108 (1953)

[6] N.K. Morozova and V.P. Morozov, Sov. Phys. Dokl. 182, 538 (1968)

[7] R. Moccia, Theoret. Chim. Acta 7, 85 (1967)

[8] S.J. Cyvin, J. Brunvoll, B.N. Cyvin, I. Elvebredd and G. Hagen, Mol. Phys. 14, 43 (1968)

[9] M. Gussoni and G. Zerbi, J. Mol. Spectrosc. 26, 485 (1968)

[10] G. Dellepiane, M. Gussoni and G. Zerbi, J. Chem. Phys. 53, 3450 (1970)

[11] G. Dellepiane, R. Tubino and L.D. Antoni Ferri, J. Chem. Phys. 57, 1616 (1972)

[12] N. Neto, J. Mol. Struct., 22, 201 (1974)

[13] B. Gellai, Studia Scient. Mathematicarum Hungarica, 6, 347 (1971)

[14] Gribov L.A., Jeljasevics M.A., Sztyepanov B.I. Volkenstein M.V.: Kolebanyija molekul, Nauka, Moszkva, (1972)

[15] P.J. Davis, Circulant Matrices, in the series Pure and Applied Mathematics, John Wiley \& Sons, New York, 1979, pp. 176-191.

[16] P. Rózsa, Linear Algebra and its Applications (in Hungarian), Müszaki Könyvkiadó, Budapest (1974), pp. 267-269. 



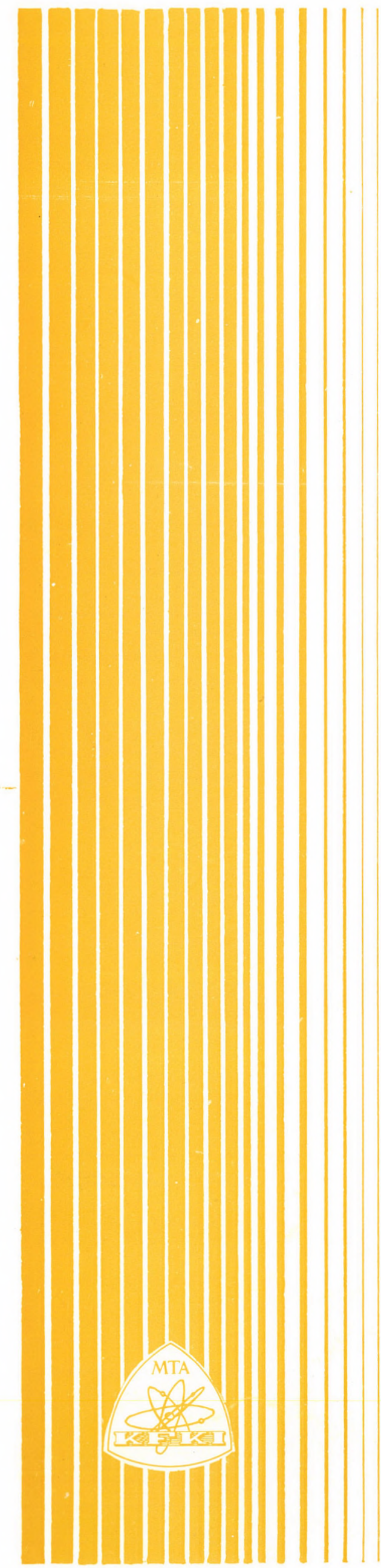

Kiadja a Központi Fizikai Kutató Intézet Felelôs kiadó: Lõcs Gyula

Szakmai lektor: Dr. Mink János Nyelvi lektor: Harvey Shenker Példányszám: 260 Törzsszám: 82-676 Készült a KFKI sokszorositó üzemében Felelôs vezetõ: Nagy Károly Budapest, 1983. február hó 